Original Article

\title{
Comparative study on the distribution and expression of Neuroglobin and Hypoxia-inducible factor- $1 \alpha$ in the telencephalon of yak and cattle
}

\author{
Estudo comparativo da distribuição e expressão de fator- $1 \alpha$ indutível por neuroglobina \\ e hipóxia no telencéfalo de iaques e bovinos

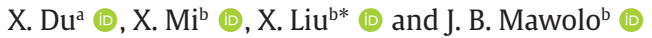 \\ ${ }^{a}$ Gansu Agricultural University, College of Veterinary Medicine, Lanzhou City, Gansu Province, People's Republic of China \\ ${ }^{\mathrm{b}}$ Gansu Agricultural University, College of Life Science and Technology, Lanzhou City, Gansu Province, People's Republic of China
}

\begin{abstract}
The telencephalon refers to the most highly developed and anterior part of the forebrain, consisting mainly of the cerebral hemispheres. The study determined Neuroglobin ( $\mathrm{Ngb}$ ) and Hypoxia-inducible factor (HIF-1 $\alpha$ ) expression in the telencephalon of yak and cattle, and compare the expression and distribution pattern of Ngb and HIF- $1 \alpha$ in the two animals. Immunohistochemistry (IHC), quantitative real-time Polymerase Chain Reaction (qRT-PCR), and Western blot $(\mathrm{WB})$ were employed to investigate $\mathrm{Ngb}$ and Hif- $1 \alpha$ expression in the telencephalon of yak and cattle. mRNA and protein expressions of Ngb and HIF- $1 \alpha$ showed positive in different tissues of the yak and cattle telencephalon. Ngb expression in tissues of the yak recorded higher as compare to cattle while HIF-1 $\alpha$ expression was found higher in cattle than yak. The HIF- $1 \alpha$ expression in some tissues of yak telencephalon was consistent with the cattle. The results documented that HIF- $1 \alpha$ may have a direct or indirect synergistic effect on Ngb expression in the yak telencephalon to improve hypoxia adaptation. It is suggested that yak may need more Ngb expression for adaptation, but the expression of HIF-1 $\alpha$ seems to be down-regulated during long-term adaptation, and the specific causes of this phenomenon needs to be further verified.
\end{abstract}

Keywords: Ngb, HIF-1 $\alpha$, yak, cattle, telencephalon.

\begin{abstract}
Resumo
O telencéfalo refere-se à parte anterior e mais desenvolvida do prosencéfalo, consistindo principalmente dos hemisférios cerebrais. $\mathrm{O}$ estudo determinou a expressão de neuroglobina ( $\mathrm{Ngb})$ e fator indutível por hipóxia (HIF-1 $\alpha$ ) no telencéfalo de iaques e bovinos e comparou a expressão e o padrão de distribuição de Ngb e HIF- $1 \alpha$ nos dois animais. Imuno-histoquímica (IHC), reação em cadeia da polimerase quantitativa em tempo real (qRT-PCR) e Western blot (WB) foram empregados para investigar a expressão de Ngb e Hif- $1 \alpha$ no telencéfalo de iaques e bovinos. As expressões de mRNA e proteínas de Ngb e HIF-1 $\alpha$ mostraram-se positivas em diferentes tecidos do telencéfalo de iaque e bovino. A expressão de Ngb nos tecidos do iaque foi registrada mais alta em comparação com o gado, enquanto a expressão do HIF-1 $\alpha$ foi encontrada mais alta no gado do que no iaque. A expressão de HIF-1 $\alpha$ em alguns tecidos do telencéfalo de iaque foi consistente com o gado. Os resultados documentaram que 0 HIF-1 $\alpha$ pode ter um efeito sinérgico direto ou indireto na expressão de Ngb no telencéfalo de iaque para melhorar a adaptação à hipóxia. É sugerido que o iaque pode precisar de mais expressão de Ngb para adaptação, mas a expressão de HIF-1 $\alpha$ parece ser regulada para baixo durante a adaptação de longo prazo, e as causas específicas desse fenômeno precisam ser verificadas.
\end{abstract}

Palavras-chave: Ngb, HIF-1 $\alpha$, iaque, gado, telencéfalo.

\section{Introduction}

Yak (Bos grunniens), as a unique livestock living in the Qinghai-Tibet Plateau with an altitude of more than 3000 meters, has an extremely strong adaptation to alpine cold and hypoxia (Song et al., 2020), and cattle are large ruminant animals with horns and cloven hoofs, domesticated for meat or milk, or as beasts of burden; cows. Some studies have showed that the brain has a strong physiological adaptability to hypoxic stimulation (Yawno et al., 2012). The telencephalon is the largest information processing centers in mammals, including cerebral cortex and corpus callosum (Montiel and Aboitiz, 2015; Yang et al., 2020), and plays an important

*e-mail: xiaohuadu123@hot.com

Received: February 19, 2021 - Accepted: March 11, 2021 
role in body movement, sensation, vision, hearing, taste, and smell (Bear et al., 2007). High-altitude hypoxia is a major physiological challenge and can be regarded as a stressful environmental condition to which organisms have the capacity to respond by adaptation (Han et al., 2017; Woo et al., 2001). In recent years, Neuroglobin (Ngb) and Hypoxia-inducible factor- $1 \alpha$ (HIF-1 $\alpha$ ), which were linked to high altitude adaptation, have been discovered. $\mathrm{Ngb}$ is a novel member of the vertebrate globin family (Burmester et al., 2000; Fordel et al., 2007), which plays a protective role in hypoxic-ischemic brain damage (Guidolin et al., 2016) while HIF-1 $\alpha$ is an important transcription regulator that can exert transcriptional activity under hypoxic conditions (Semenza and Wang, 1992; Mohindra et al., 2013) and plays an important regulatory role in the regulation of cerebral ischemia and hypoxia (Erler et al., 2004; Vangeison et al., 2008). Studies showed that HIF- $1 \alpha$ can promote Ngb production in ischemic and hypoxic brain damage (Moens and Dewilde, 2000; Hundahl et al., 2005; Liu et al., 2012; Haines et al., 2012). Despite these reported references, a connection between HIF-1 $\alpha$ and Ngb has not been demonstrated in the telencephalon of yak and cattle. Therefore, the current study provided insight about the distribution and expression pattern of Ngb and HIF-1 $\alpha$ in different regions of yak telencephalon by using a quantitative real-time polymerase chain reaction (qRT-PCR), Western-blotting and immunohistochemistry, and compared with the cattle. These results provided valuable morphological to understand the function and mechanism of Ngb and HIF$1 \alpha$ in the yaks' brain. Furthermore, the discovery paved the way for more research into the physiological roles of Ngb and HIF-1 in brain hypoxic injury-related diseases.

\section{Materials and Methods}

\subsection{Animals and setting}

The experimental protocols were reviewed and approved by the Animal Ethics and Welfare Committee of Gansu Agricultural University, Gansu Province in October 2019 with regard to the protection of animals used in research and scientific purposes. Approval No. AEWC-GAU-2019-039. Five (5) Healthy male adult yak and cattle heads were purchased from the cooperative cities of Gannan Tibetan Autonomous Prefecture in Gansu Province and Zhengzhou in Henan Province, China respectively. The altitude in Gannan Tibetan Autonomous Prefecture was $3000 \mathrm{~m}$ which was a plateau environment while in the Zhengzhou of Henan Province, the altitude was $500 \mathrm{~m}$ which was a plain environment. The entire brain tissue was quickly extracted by craniotomy and the tissue samples taken from different regions of the telencephalon, including the cerebral cortex (frontal lobe, parietal lobe, temporal lobe, occipital lobe), white matter, piriform lobe, hippocampus, basal ganglia, cingulate gyrus, and corpus callosum. Samples prepared for immunohistochemistry were fixed in $4 \%$ paraformaldehyde ( $\mathrm{PH} \mathrm{7.4,} \mathrm{w/v)} \mathrm{and}$ samples for quantitative reverse transcription-polymerase chain reaction (qRT-PCR) and Western-blotting were stored at $-80{ }^{\circ} \mathrm{C}$.

\subsection{Animals}

The entire brain tissue was quickly extracted by craniotomy and the tissue samples taken from different regions of the telencephalon, including the cerebral cortex (frontal lobe, parietal lobe, temporal lobe, occipital lobe), white matter, piriform lobe, hippocampus, basal ganglia, cingulate gyrus, and corpus callosum. Samples prepared for immunohistochemistry were fixed in $4 \%$ paraformaldehyde ( $\mathrm{PH} 7.4, \mathrm{w} / \mathrm{v}$ ) and samples for quantitative reverse transcription-polymerase chain reaction (qRT-PCR) and Western-blotting were stored at $-80^{\circ} \mathrm{C}$.

\subsection{Reagents and instrumentations}

AG RNAex Pro RNA kit, SYBR Green Pro Taq HS kit, Evo M-MLV reverse-transcription kit (removal gDNA reagent), and Rox were purchased from Accurate Biotechnology (Hunan) Co. Ltd. P.R. China. Rabbit Anti-Ngb, Polyclonal Antibody (bs-1859R), Rabbit Anti-HIF-1 $\alpha$, Alpha Polyclonal Antibody (bs-0737R), Rabbit Anti-beta-Actin (Loading Control), Polyclonal antibody (bs-0737R) and goat antirabbit IgG/HRP(bs-0295G-HRP) were purchased from Bioss Co. Ltd. P.R. China. Radio Immunoprecipitation Assay (RIPA) was purchased from Biotopped Co. Ltd. P.R. China. 0.22 $\mu \mathrm{m}$ polyvinylidene fluoride(PVDF), 4×protein loading buffer (dithiothreitol, DTT), Rainbow 245 broad-spectrum protein marker (11-245 KDa), and enhanced chemi-luminescence (ECL) hypersensitivity luminescent solution were purchased from Solarbio Co. Ltd. P.R. China. Immunohistochemical staining kit and HRP-DAB kit were purchased from Beijing Zhongshan Golden Bridge Biotechnology Co. Ltd. P.R. China.

\subsection{Total RNA isolation and $q R T-P C R$}

Total RNA was isolated using the TRIzol reagent (Accurate Biotechnology, China). Eight hundred nanograms of total RNA was reverse transcribed using the Evo M-MLV cDNA synthesis kit (Accurate Biotechnology, China). Real-time PCR was performed using Quant Studio 5. The qRT-PCR primer sequences and accession numbers are shown in Table 1 . Reaction mixtures $(20 \mu \mathrm{L})$ consisted of $10 \mu \mathrm{L}$ SYBR Green Pro Taq (Accurate Biotechnology, China), $0.8 \mu \mathrm{L}$ forward and reverse primers $(0.2 \mu \mathrm{mol} / \mathrm{mL}), 0.4 \mu \mathrm{L}$


$50{ }^{\circ} \mathrm{C} 2 \mathrm{~min}, 95^{\circ} \mathrm{C} 2 \mathrm{~min}, 40$ cycles at $95^{\circ} \mathrm{C} 10 \mathrm{~s}$, annealing for $34 \mathrm{~s}$ (annealing temperatures are shown in Table 1), with melting temperatures examined from $65^{\circ} \mathrm{C}$ to $95^{\circ} \mathrm{C}$, increments of $0.5^{\circ} \mathrm{C}$ every $5 \mathrm{~s}$. Each sample is repeated 3 times $(n=3)$, the results are averaged. The $2^{-\Delta \Delta c t}$ method was used to analyze the expression of NGB and HIF-1a mRNA relative to $\beta$-actin mRNA expression according to the system-generated $\mathrm{Ct}$ value.

\subsection{Western-blotting}

For Western-blotting analyses (Song et al., 2018), frozen tissue samples from different regions of yak and cattle telencephalon were weighed. Then, the tissues were homogenized using a glass rod in lysis buffer $(1 \mathrm{ml}$ 
Table 1. Primer sequences of target and house-keeping genes.

\begin{tabular}{|c|c|c|c|c|c|}
\hline $\begin{array}{l}\text { Primer } \\
\text { name }\end{array}$ & $\begin{array}{l}\text { Accession } \\
\text { numbers }\end{array}$ & Sequence(5' to 3') & $\mathrm{Tm} /{ }^{\circ} \mathrm{C}$ & $\begin{array}{l}\text { Amplicon } \\
\text { size }\end{array}$ & Note \\
\hline \multirow[t]{2}{*}{ Ngb } & JQ241373.1 & F:CTTTCGCCAGGCTGTTTGA & 60.0 & 134 & qRT-PCR \\
\hline & & R:CTGATGTGGTCCAGGAACTCG & & & \\
\hline \multirow[t]{2}{*}{ HIF- $1 \alpha$} & NM_174339.3 & F:CTACATTACCTGCCTCTGAАACTCC & 59.8 & 146 & qRT-PCR \\
\hline & & R:ACGCTTTGTCTGGTGCTTCC & & & \\
\hline \multirow[t]{2}{*}{$\beta$-actin } & NM_173979.3 & F: ATATTGCTGCGCTCGTGGT & 60.2 & 158 & qRT-PCR \\
\hline & & R:TCATCCCCCACGTACGAGTC & & & \\
\hline
\end{tabular}

qRT-PCR - quantitative real-time polymerase chain reaction; $\mathrm{Tm}$ - temperature.

RIPA $+10 \mu L$ phenyl methane sulfonyl fluoride (PMSF)) at ice-cold temperature. The protein was subjected to SDS polyacrylamide gel electrophoresis (PAGE). Separated proteins were transferred to a polyvinylidene difluoride filter (PVDF) membrane via the transfer apparatus at $110 \mathrm{~V}$ for $60 \mathrm{~min}$. The membranes were blocked overnight at $4{ }^{\circ} \mathrm{C}$ with $5 \%$ milk/PBST, and incubated with primary antibody of rabbit anti-Ngb, anti HIF- $1-\alpha$ and anti- $\beta$-actin polyclonal antibody (1:800, 1:500, 1:3000, Bioss, China, bs-1859R, bs-0737R and bs-0737R). The membranes were then incubated with the secondary antibody of HRP-conjugated goat anti-rabbit IgG (1:4000, Bioss, China, bs-0295G-HRP), and then scanned with the ECL Western-blotting machine (GE AI600, America). Each group of protein was repeated 3 times $(n=3)$. The signals were analyzed with Image J software (NIH, Bethesda, MD, USA) to determine the relative expression levels of Ngb and HIF-1- $\alpha$.

\subsection{Immunohistochemical staining}

Tissue samples from different regions of yak and cattle telencephalon were dehydrated, embedded with paraffin, and cut into 4 - $\mu \mathrm{m}$-thick sections, hematoxylin-eosin (HE) routine staining. The sections were rehydrated, repaired with $0.125 \%$ trypsin antigen, blocked with $5 \%$ goat serum, and incubated at $37^{\circ} \mathrm{C}$ with the primary antibody of rabbit anti-Ngb, anti-HIF- $1 \alpha$ polyclonal antibody (1:400, Bioss, China, bs-1859R and bs-0737R). The sections were then incubated with the secondary antibody, and then added with streptomyces avidin-peroxidase solution. The immunoperoxidase color reaction was developed with the HRP-DAB substrate chromogen solution. The labeled samples were then counterstained with hematoxylin. Negative controls were performed by substituting the primary antibody with PBS $(0.01 \mathrm{~mol} / \mathrm{L}, \mathrm{pH}=7.2)$. Then the sections were observed and photographed with an Olympus-DP73 optical microscope (Tokyo, Japan).

\subsection{Anesthesia or euthanasia procedures}

Under the legislation of Gansu Agricultural University's Animal Ethics and Protection Committee, all animals involved in the study were placed separately until they It has been confirmed to be safe. The animals were observed for two weeks before further procedures were conducted according to the committee regulations. Although under observation, the animals were free and the observation indicated that the animals were free of any infectious diseases which may have an adverse effect on the experimental procedures. The diet of the animals was given during observation and no shortage of food. To stop pain or mitigate it, the animals were treated calmly by trained personnel. Dealing with these large animals requires more personnel, so additional trained personnel were employed for assistance during the sacrifice. The animals were spoken to by the personnel and loud sounds were avoided to avoid the animals escaping. More food was simultaneously given to the animals to enable interaction between the animals and the personnel and supported a developing relationship with the personnel. The animals were made to lie on their side by scratching their back and flanks by the personnel. While in a calm state, the injections were administrated and scarification took place.

\subsection{Animals housing conditions}

In Hezuo town, Gansu Province, the People's Republic of China, the Hezuo Xingfa Yak and sheep breeding collaboration is located. Hezuo has a subarctic alpine climate at nearly 3,000 meters $(9,800 \mathrm{ft})$ in altitude, with winters that are long, very cold, dry, and short, mild summers. In January, the coldest month, the monthly standard everyday temperature is $-9.3^{\circ} \mathrm{C}\left(15.3^{\circ} \mathrm{F}\right)$, while in July, the warmest month, the same figure is $13.3^{\circ} \mathrm{C}\left(55.9^{\circ} \mathrm{F}\right)$; the annual average is $2.82^{\circ} \mathrm{C}\left(37.1^{\circ} \mathrm{F}\right)$. The bulk of annual precipitation is distributed from May to September. The town receives 2,370 hours of bright sunshine annually, with monthly percent of potential sunshine ranging from 44 percent in June and September to $71 \%$ in December.

\subsection{Data analysis}

Statistical analyses were performed using SPSS version 19.0 (SPSS, Inc., Chicago, IL, USA). All data were tested for normality and homoscedasticity and then subjected to a one-way analysis of variance followed by Duncan's multiple tests to detect significant differences. All quantitative data are presented as the mean \pm SEM. $P<0.05$ and $P<0.01$ was considered statistically significant. The expressions intensity was analyzed using image J software and calculated according to the software standard value. 


\section{Results}

3.1. Expression of $\mathrm{Ngb} m R N A$ and protein in the different regions of yak and cattle telencephalon

Table 1 shows the Primer sequences and targeted gene sequences. Ngb mRNA and protein were positive in all regions of yak and cattle telencephalon, and the highest expression of Ngb mRNA (Yak: $18.736 \pm 1.270$, Cattle: 5.735 \pm 0.103 ; Figure 1A) and protein (Figure 1B) were the parietal lobe of yak and cattle telencephalon. Its reported significantly higher than in other regions $(P<0.05)$. In yak, the expression of Ngb mRNA was lowest in piriform lobe,
A

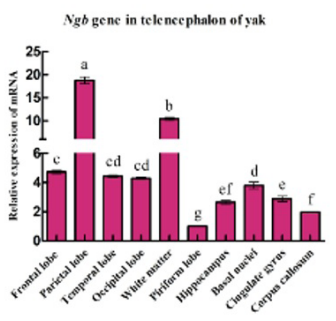

B

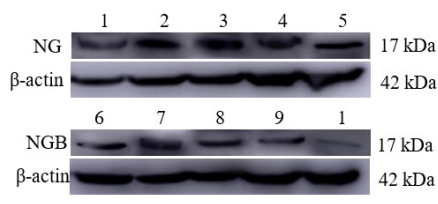

Ngb protein in telencephalon of yak

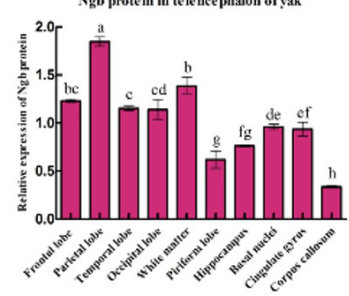

C

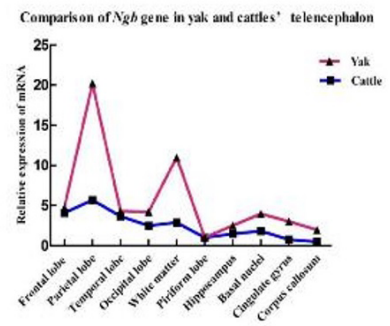

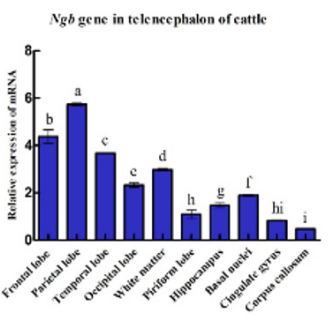

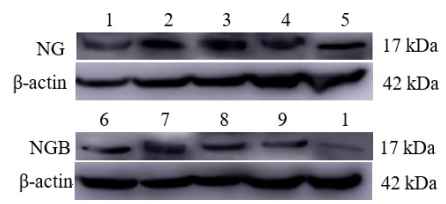

Ngb protein in te lencephalon of cattle

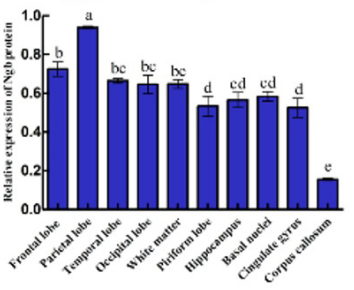

Comparison of Ngb prote in in yalk and cattles' tele ncephalo

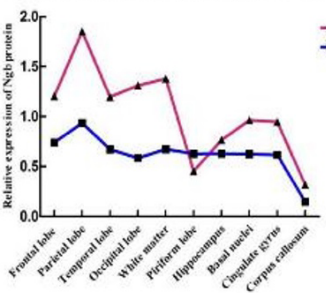

\begin{tabular}{|l|l|l|l|}
\hline Annex 1 (A1) & Annex 1 (B1) & Annex 1 (C1) & Annex 1 (D1) \\
\hline Annex 1 (A2) & Annex 1 (B2) & Annex 1 (C2) & Annex 1 (D2) \\
\hline Annex 1 (A3) & Annex 1 (B3) & Annex 1 (C3) & Annex 1 (D3) \\
\hline Annex 1 (A4) & Annex 1 (B4) & Annex 1 (C4) & Annex 1 (D4) \\
\hline Annex 1 (A5) & Annex 1 (B5) & Annex 1 (C5) & Annex 1 (D5) \\
\hline Annex 1 (A6) & Annex 1 (B6) & Annex 1 (C6) & Annex 1 (D6) \\
\hline Annex 1 (A7) & Annex 1 (B7) & Annex 1 (C7) & Annex 1 (D7) \\
\hline Annex 1 (A8) & Annex 1 (B8) & Annex 1 (C8) & Annex 1 (D8) \\
\hline Annex 1 (A9) & Annex 1 (B9) & Annex 1 (C9) & Annex 1 (D9) \\
\hline Annex 1 (A10) & Annex 1 (B10) & Annex 1 (C10) & Annex 1 (D10) \\
\hline
\end{tabular}

Figure 1. The HE and Immunohistochemical results in different regions of yak telencephalon. Note: (A) HE staining results of HIF-1 $\alpha$ mRNA and protein in the different regions of yak and cattle telencephalon. Relative expression of HIF-1 $\alpha$ mRNA in yak and cattle telencephalon; (B) Relative expression of HIF-1 $\alpha$ protein in yak and cattle telencephalon. 1-10: Frontal lobe, Parietal lobe, Temporal lobe, Occipital lobe, White matter, Piriform lobe, Hippocampus, Basal nuclei, Cingulate gyrus, Corpus callosum; (C) Comparison results. Data in the nd same column with the same letter means no significant difference $(P>0.05)$, with different letter means difference significantly (between a and b, b and c, c and d, d and e, e and f, f and g, $g$ and h, h and i, P < 0.05; between a and c, c and e, e and g, g and i, P < 0.01). 
and the lowest expression of $\mathrm{Ngb}$ protein was the corpus callosum while the expression of Ngb mRNA and protein were lowest in corpus callosum of cattle as reported in Table 2. In comparison, the expression of Ngb mRNA in different regions of yak's telencephalon was higher as compared to the cattle. The expression of Ngb mRNA in the frontal lobe, the temporal lobe, and the piriform lobe of yak and cattle were basically consistent.

3.2. Localization of $\mathrm{Ngb}$ and HIF-1 $\alpha$ protein in the different regions of yak and cattle telencephalon

The HE staining results of yak and cattle telencephalon (Figure 2 A1-A10; a1-a10) showed that the frontal lobe was predominantly composed of granular cells. In addition, the parietal lobe, temporal lobe, and occipital lobe were mainly made of granular cells and Martinotti cells. The structure of the white matter region was similar to that of the cingulate gyrus, consisting of the nerve glial cells and nerve fibers. The corpus callosum were mainly made of the nerve glial cells and few poly-type cells. Basal nuclei and piriform lobe were mainly composed of poly-type cells or Martinotti cells. The hippocampus was mainly divided into a molecular cell layer, a pyramidal cell layer, and a poly-type cell layer, and there are some differences in the structure of yak and cattle. Meanwhile Table 3 reported qRT-PCR results of $\mathrm{Ngb}$ and HIF-1 $\alpha$ expression in the regions of the yak and cattle.

Immunohistochemical results showed that the distribution of Ngb and HIF-1 $\alpha$ positive cells in the cattle

Table 2. Quantitative real-time polymerase chain reaction ( $\mathrm{qRT}$-PCR) results of $\mathrm{Ngb}$ in different regions of yak and cattle's telencephalon, $($ mean \pm SED).

\begin{tabular}{|c|c|c|c|c|c|c|}
\hline \multirow{2}{*}{$\begin{array}{c}\text { Tissues and } \\
\text { organs }\end{array}$} & \multicolumn{3}{|c|}{ Yak } & \multicolumn{3}{|c|}{ Cattle } \\
\hline & $\Delta \mathrm{CT}$ & $\Delta \Delta \mathrm{CT}$ & $2^{-\Delta \Delta C T}$ & $\Delta \mathrm{CT}$ & $\Delta \Delta \mathrm{CT}$ & $2^{-\Delta \Delta C T}$ \\
\hline Frontal lobe & $10.707 \pm 0.066$ & $-2.238 \pm 0.066$ & $4.720 \pm 0.214$ & $8.842 \pm 0.164$ & $-2.123 \pm 0.1642$ & $4.376 \pm 0.513$ \\
\hline Parietal lobe & $8.719 \pm 0.096$ & $-4.226 \pm 0.096$ & $18.736 \pm 1.270$ & $8.446 \pm 0.026^{*}$ & $-2.520 \pm 0.026^{*}$ & $5.735 \pm 0.103$ \\
\hline Temporal lobe & $10.797 \pm 0.042^{*}$ & $-2.148 \pm 0.042^{*}$ & $4.432 \pm 0.129$ & $9.087 \pm 0.012^{*}$ & $-1.878 \pm 0.012^{*}$ & $3.676 \pm 0.030^{*}$ \\
\hline Occipital lobe & $10.843 \pm 0.042^{*}$ & $-2.101 \pm 0.042^{*}$ & $4.291 \pm 0.126$ & $9.748 \pm 0.106$ & $-1.217 \pm 0.106$ & $2.329 \pm 0.169$ \\
\hline White matter & $9.569 \pm 0.078$ & $-3.376 \pm 0.078$ & $10.389 \pm 0.565$ & $9.393 \pm 0.049^{*}$ & $-1.572 \pm 0.049^{*}$ & $2.975 \pm 0.102$ \\
\hline Piriform lobe & $12.923 \pm 0.054^{*}$ & $-0.021 \pm 0.054^{*}$ & $1.015 \pm 0.039^{*}$ & $10.860 \pm 0.384$ & $-0.105 \pm 0.384$ & $1.102 \pm 0.305$ \\
\hline Hippocampus & $11.537 \pm 0.118$ & $-1.407 \pm 0.118$ & $2.658 \pm 0.223$ & $10.413 \pm 0.169$ & $-0.552 \pm 0.1690$ & $1.473 \pm 0.172$ \\
\hline Basal nuclei & $11.022 \pm 0.152$ & $-1.922 \pm 0.152$ & $3.803 \pm 0.390$ & $10.040 \pm 0.044^{*}$ & $-0.925 \pm 0.044^{*}$ & $1.899 \pm 0.058^{*}$ \\
\hline $\begin{array}{l}\text { Cingulate } \\
\text { gyrus }\end{array}$ & $11.425 \pm 0.164$ & $-1.519 \pm 0.164$ & $2.879 \pm 0.316$ & $11.252 \pm 0.081$ & $0.286 \pm 0.081$ & $0.821 \pm 0.045^{*}$ \\
\hline $\begin{array}{l}\text { Corpus } \\
\text { callosum }\end{array}$ & $11.961 \pm 0.008^{*}$ & $-0.983 \pm 0.008^{*}$ & $1.977 \pm 0.011^{*}$ & $12.028 \pm 0.048^{*}$ & $1.062 \pm 0.048^{*}$ & $0.479 \pm 0.016^{*}$ \\
\hline
\end{tabular}

The * represents the significant level while the $\mathrm{CT}$ indicates the different delta variance.

Table 3. Quantitative real-time polymerase chain reaction (qRT-PCR) results of HIF-1 $\alpha$ gene in different regions of yak and cattle's telencephalon, (Mean \pm SED).

\begin{tabular}{|c|c|c|c|c|c|c|}
\hline \multirow{2}{*}{$\begin{array}{c}\text { Tissues and } \\
\text { organs }\end{array}$} & \multicolumn{3}{|c|}{ Yak } & \multicolumn{3}{|c|}{ Cattle } \\
\hline & $\Delta \mathrm{CT}$ & $\Delta \Delta \mathrm{CT}$ & $2^{-\Delta \Delta C T}$ & $\Delta \mathrm{CT}$ & $\Delta \Delta \mathrm{CT}$ & $2^{-\Delta \Delta C T}$ \\
\hline Frontal lobe & $5.212 \pm 0.145$ & $-1.852 \pm 0.145$ & $3.621 \pm 0.352$ & $2.255 \pm 0.041^{*}$ & $-2.320 \pm 0.041^{*}$ & $4.996 \pm 0.141$ \\
\hline Parietal lobe & $4.012 \pm 0.235$ & $-3.052 \pm 0.235$ & $8.367 \pm 1.364$ & $2.050 \pm 0.091$ & $-2.525 \pm 0.091$ & $5.762 \pm 0.355$ \\
\hline Temporal lobe & $5.275 \pm 0.058^{*}$ & $-1.79 \pm 0.058^{*}$ & $3.457 \pm 0.141$ & $2.421 \pm 0.079$ & $-2.154 \pm 0.079$ & $4.456 \pm 0.241$ \\
\hline Occipital lobe & $5.443 \pm 0.059^{*}$ & $-1.620 \pm 0.059^{*}$ & $3.076 \pm 0.127$ & $2.796 \pm 0.087^{*}$ & $-1.779 \pm 0.087$ & $3.435 \pm 0.207$ \\
\hline White matter & $4.675 \pm 0.109$ & $-2.389 \pm 0.109$ & $5.245 \pm 0.387$ & $2.452 \pm 0.040^{*}$ & $-2.123 \pm 0.040^{*}$ & $4.358 \pm 0.122$ \\
\hline Piriform lobe & $7.046 \pm 0.076$ & $-0.018 \pm 0.076$ & $1.013 \pm 0.054^{*}$ & $4.696 \pm 0.121$ & $0.121 \pm 0.121$ & $0.922 \pm 0.077$ \\
\hline Hippocampus & $6.174 \pm 0.044^{*}$ & $-0.890 \pm 0.044^{*}$ & $1.854 \pm 0.056^{*}$ & $3.186 \pm 0.066$ & $-1.389 \pm 0.066$ & $2.621 \pm 0.121$ \\
\hline Basal nuclei & $5.595 \pm 0.119$ & $-1.468 \pm 0.119$ & $2.773 \pm 0.224$ & $2.943 \pm 0.058^{*}$ & $-1.632 \pm 0.058^{*}$ & $3.101 \pm 0.126$ \\
\hline $\begin{array}{l}\text { Cingulate } \\
\text { gyrus }\end{array}$ & $5.888 \pm 0.155$ & $-1.176 \pm 0.155$ & $2.268 \pm 0.240$ & $3.605 \pm 0.270$ & $-0.970 \pm 0.270$ & $1.981 \pm 0.356$ \\
\hline $\begin{array}{l}\text { Corpus } \\
\text { callosum }\end{array}$ & $7.009 \pm 0.028^{*}$ & $-0.054 \pm 0.028^{*}$ & $1.038 \pm 0.019^{*}$ & $5.026 \pm 0.065$ & $0.451 \pm 0.065$ & $0.732 \pm 0.032^{*}$ \\
\hline
\end{tabular}

The * represents the significant level while the CT indicates the different delta variance. 

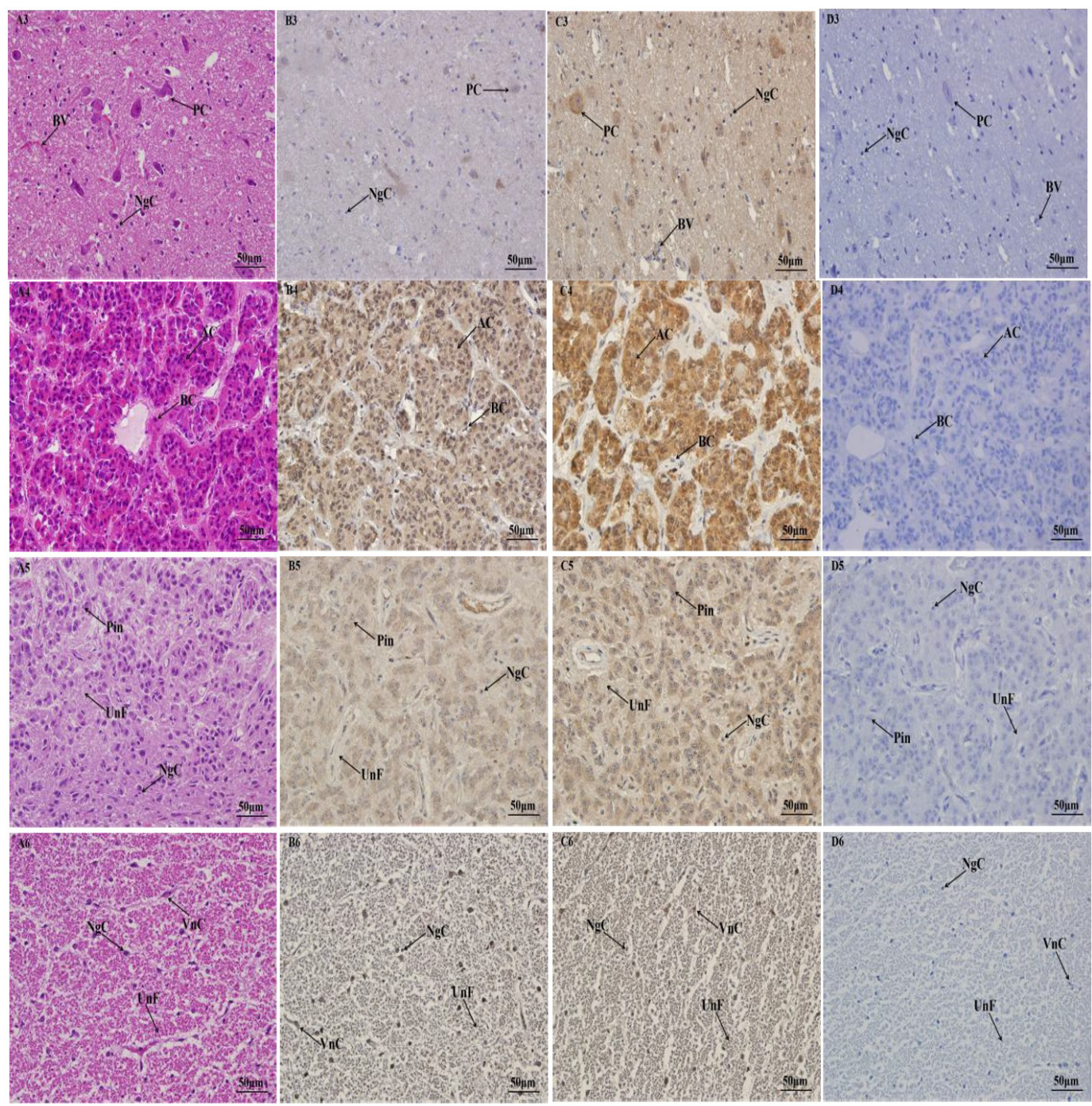

\begin{tabular}{|l|l|l|l|}
\hline Annex 2 (a1) & Annex 2 (b1) & Annex 2 (c1) & Annex 2 (d1) \\
\hline Annex 2 (a2) & Annex 2 (b2) & Annex 2 (c2) & Annex 2 (d2) \\
\hline Annex 2 (a3) & Annex 2 (b3) & Annex 2 (c3) & Annex 2 (d3) \\
\hline Annex 2 (a4) & Annex 2 (b4) & Annex 2 (c4) & Annex 2 (d4) \\
\hline Annex 2 (a5) & Annex 2 (b5) & Annex 2 (c5) & Annex 2 (d5) \\
\hline Annex 2 (a6) & Annex 2 (b6) & Annex 2 (c6) & Annex 2 (d6) \\
\hline Annex 2 (a7) & Annex 2 (b7) & Annex 2 (c7) & Annex 2 (d7) \\
\hline Annex 2 (a8) & Annex 2 (b8) & Annex 2 (c8) & Annex 2 (d8) \\
\hline Annex 2 (a9) & Annex 2 (b9) & Annex 2 (c9) & Annex 2 (d9) \\
\hline Annex 2 (a10) & Annex 2 (b10) & Annex 2 (c10) & Annex 2 (d10) \\
\hline
\end{tabular}

Figure 2. The HE and Immunohistochemical results in different regions of yak telencephalon. Note: (A) HE staining results; (B) Immunohistochemical results of NGB protein; (C) Immunohistochemical results of HIF-1 $\alpha$ protein; (D) Negative control. The scale is $50 \mu \mathrm{m}$. 1-10: Frontal lobe, Parietal lobe, Temporal lobe, Occipital lobe, White matter, Piriform lobe, Hippocampus, Basal nuclei, Cingulate gyrus, Corpus callosum. Nerve glial cell,: Blood vessel, Granular cell, Martinotti cell, Nerve fiber, Polytype cell, Polytype cell layer, Pyramidal cell layer, Molecular cell layer. 
telencephalon were similar to those in the yak. Each regions of the cerebral cortex, Ngb and HIF-1 $\alpha$ positive cells are widely distributed in the neuron cytoplasm (Figure 3 B1-4, Figure 3 C1-4, Figure 3 B6, B8, B10, Figure 3 C6, C8, C10), which were coincident with piriform lobe, basal nuclei, and corpus callosum (Figure 4 b5, b6, b8, b7, b9, b10; Figure 4 b1-4; Figure 4 C1-4Figure 4 c5, c6, c7, c8, c9, c10).

\section{Discussion}

A few studies have focused on the comparison of expression and distribution of Ngb mRNA and protein in different regions of other mammals, but none have reported the expression and distribution of $\mathrm{Ngb}$ and $\mathrm{mRNA}$ expression in the telencephalon of yak and cattle. Ngb is a respiratory protein that is preferentially expressed in

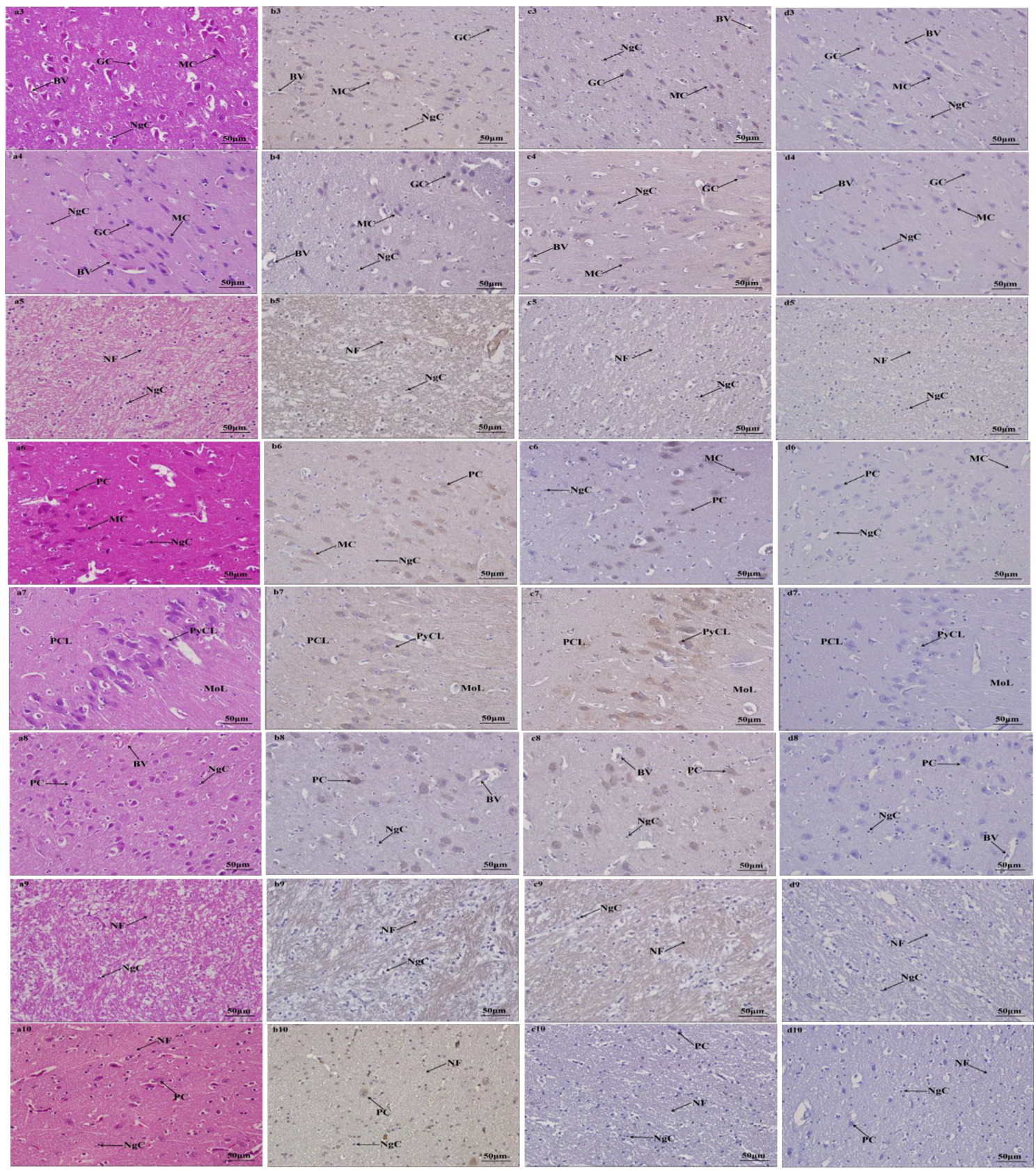

Figure 3. The HE and Immunohistochemical results in different regions of cattle telencephalon. Note: (a) HE staining results; (b) Immunohistochemical results of NGB protein; (c) Immunohistochemical results of HIF-1 $\alpha$ protein; (d) Negative control. The scale is 50 $\mu \mathrm{m}$. 1 10: Frontal lobe, Parietal lobe, Temporal lobe, Occipital lobe, White matter, Piriform lobe, Hippocampus, Basal nuclei, Cingulate gyrus, Corpus callosum. Nerve glial cell, Blood vessel, Granular cell, Martinotti cell, Nerve fiber, Polytype cell, Polytype cell layer, Pyramidal cell layer, Molecular cell layer. 
$H I F-I a$ gene in telencephalon or yak

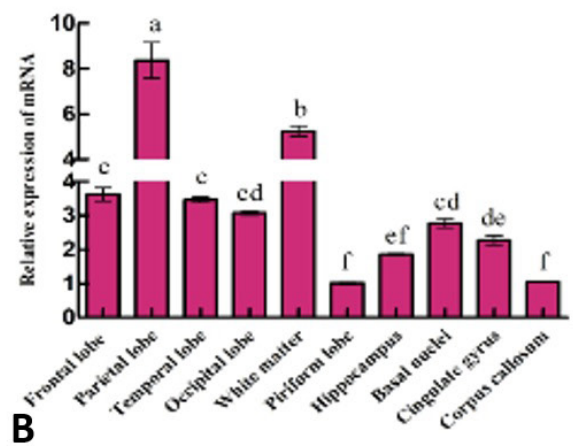

$H I F-1 \alpha$ gene in telencephalon of cattle

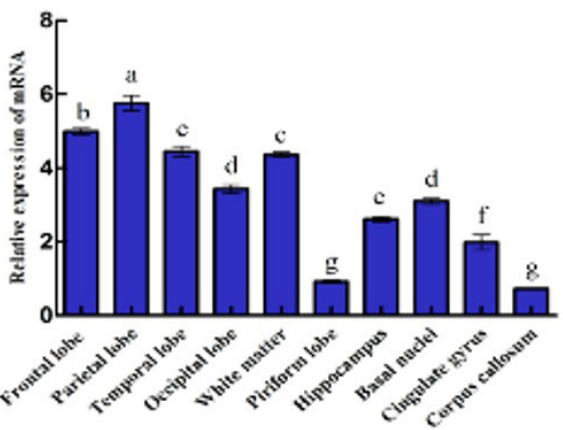

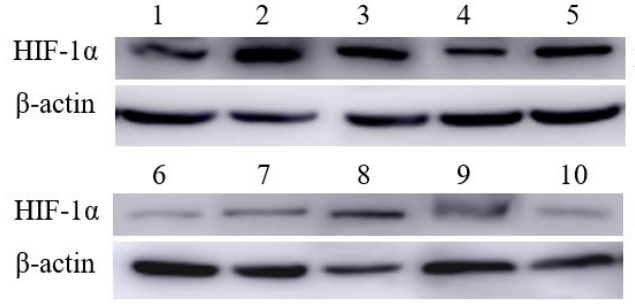

HIF-la prote in in telencephalon of yuk

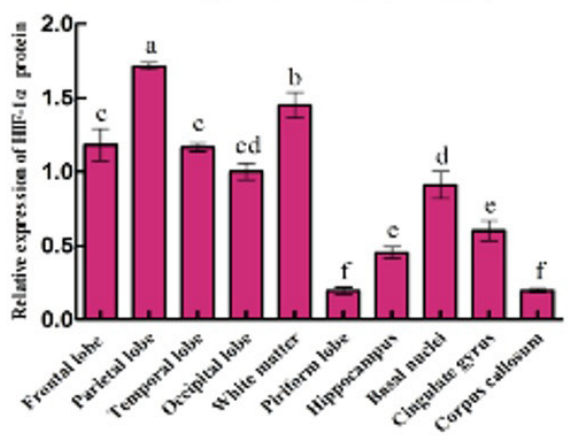

C

Comparis on of HIF-Ia gene in yak and eattles' telencephalon

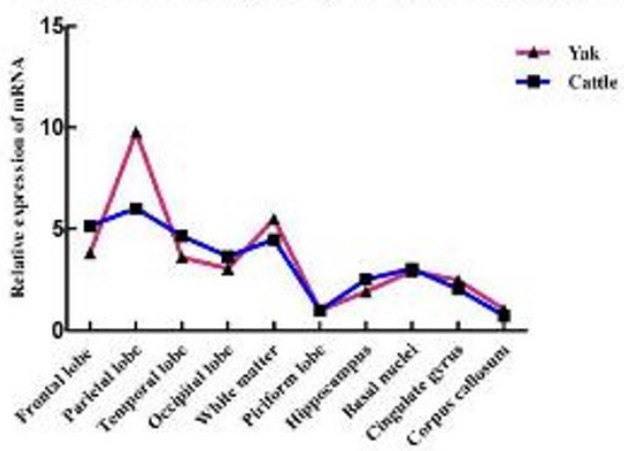

HIF-1 a protein in tele nce phulon of cattle

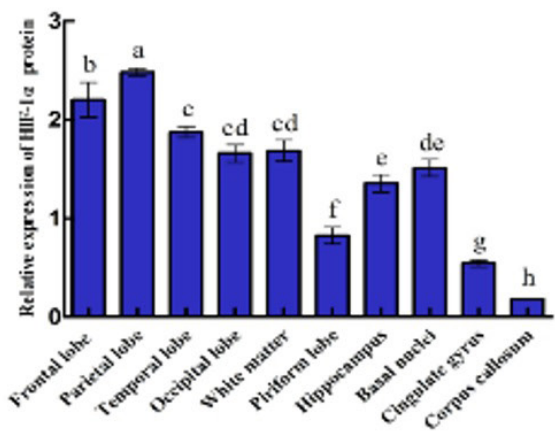



Figure 4. The expression results of HIF- $1 \alpha$ mRNA and protein in the different regions of yak and cattle telencephalon. Note: a: HE staining results. b: Immunohistochemical results of NGB protein. c: Immunohistochemical results of HIF-1 $\alpha$ protein. d: Negative control. The scale is $50 \mu \mathrm{m}$. 1 10: Frontal lobe, Parietal lobe, Temporal lobe, Occipital lobe, White matter, Piriform lobe, Hippocampus, Basal nuclei, Cingulate gyrus, Corpus callosum. Nerve glial cell, Blood vessel, Granular cell, Martinotti cell, Nerve fiber, Polytype cell, Polytype cell layer, Pyramidal cell layer, Molecular cell layer. 
the central and peripheral nervous system of vertebrates (Burmester et al., 2000). A recent study reported that more than 200 transcriptome datasets from the mouse and 130 datasets from other species, including man, cattle, sheep and pig showed high expression of Ngb mRNA in various regions of the mammalian brain (Fabrizius et al., 2016). Prominent Ngb mRNA protein expression was detected in the human, mouse, rat, pufferfish and zebrafish brain (Awenius et al., 2001; Zhang et al., 2002). In the present study, Ngb mRNA and protein were positive in all regions of yak and cattle telencephalon, which also proved the conservation of $\mathrm{Ngb}$ evolution in the yak and cattle nervous system. In addition, the study revealed that Ngb protein expressed in different regions of the yak telencephalon were higher as compared to the cattle. This suggest that the alpine and hypoxic environment need more Ngb for yak adaptation.

$\mathrm{Ngb}$ expression also appears to vary by region in the yak and cattle telencephalon. The expression level of $\mathrm{Ngb}$ in the parietal lobe $(P<0.05)$ recorded the highest, and the expression results were consistent in both yak and cattle. The parietal lobe is located between the frontal lobe and occipital lobe (The Neuroscientist, 2017; Abhang et al., 2016), and it was involved in a number of complex tasks involving attention, integration of information such as recognition, visuospatial abilities and appreciation of environmental cues and the appropriate connection of sensory input to action (Cheng et al., 2020; Mehler and Reschechtko, 2018; Caspers and Zilles, 2018). Therefore, in order to maintain the steady-state environment in the parietal lobe of yak and cattle, Ngb may play a positive role. Studies observed that Ngb expression was inversely related to the sensitivity of the corresponding region to ischemia and hypoxia (Reuss et al., 2002). Therefore, the parietal lobe ischemia hypoxia in yak has the weakest sensitivity and the highest tolerance; the corpus callosum has the strongest sensitivity and the weakest tolerance to ischemia and hypoxia. In addition, the expression of Ngb in white matter was higher in yak as compared to the cortex, but no significant in the cattle, suggesting that the white matter may require a large amount of $\mathrm{Ngb}$ in adapting to the plateau hypoxia environment.

A family of highly conserved transcription factorshypoxia-inducible factors (HIF) plays an important role in the regulation of oxygen homeostasis. The key role in this process has now been established to belong to the oxygen-sensitive transcription factor HIF-1 $\alpha$ (Ju et al., 2016; Chertok and Kotsyuba, 2017). Researchers reported that HIF-1 $\alpha$ are expressed in the central nervous system (CNS) of mammals (Mohindra et al., 2013; López-Hernández et al., 2012; Chertok et al., 2018). The current study reported that HIF- $1 \alpha$ mRNA and protein were positive in all regions of yak and cattle telencephalon, which was consistent with other species. According to modern concepts, HIF-1a expressed in almost all mammalian nervous cells has long been considered as the main mediator of the adaptive processes in hypoxia, and took part in neuroprotective mechanisms in hypoxia/ischemia and oxidative stress (Vangeison et al., 2008; López-Hernández et al., 2012). However, some studies have shown that the expression of HIF- $1 \alpha$ would increase significantly in a short time under the condition of hypoxia stress, and HIF- $1 \alpha$ might not be expressed or down-regulated during long-term adaptation to the hypoxic environment (Ju et al., 2016; Bani Hashemi et al., 2008). This study recorded that the expression level of HIF- $1 \alpha$ mRNA in yak and cattle was basically similar, while the HIF- $1 \alpha$ protein expression level was higher in cattle than in yak, indicating that HIF-1 $\alpha$ may be down-regulated during the long-term adaptation of yak to the high altitude environment.

In yak and cattle telencephalon, the expression level of HIF- $1 \alpha$ was the highest in the parietal lobe $(\mathrm{P}<0.05)$, which was consistent with the expression pattern of $\mathrm{Ngb}$. It was reported that HIF- $1 \alpha$ can regulate $\mathrm{Ngb}$ expression in the neural cells (Van Acker et al., 2019). Our results indicate that there exists a relationship between Ngb and HIF- $1 \alpha$. In Several studies have shown that HIF-1 $\alpha$ was highly expressed in the cerebral cortex (Chertok and Kotsyuba, 2017; Wu et al., 2008; Bai et al., 2019). The current study demonstrated for the first time that HIF-1 $\alpha$ was highly expressed in the parietal lobe, further indicating that the parietal lobe was the most susceptible site to hypoxia in the cerebral cortex. In addition, the expression of HIF$1 \alpha$ in white matter was significantly higher in yak as compared to other tissues, but no significant difference was found in cattle, suggesting that the white matter is more susceptible to hypoxia, during the yak adapting to the plateau hypoxic environment.

Integrated immunohistochemical analysis showed that in the cerebral cortex of yak and cattle, Ngbimmunoreactive (-IR) neurons were observed in all cortical layers, which was consistent with other described species (Burmester et al., 2000; Wystub et al., 2003). Ngb in other regions of yak and cattle, such as the piriform lobe, hippocampus, and basal nuclei, were mainly expressed in the neuronal cytoplasm, which was consistent with the results of Cao (Liang, 2013) and Li (Tong-Fang, 2014). In addition, Ngb protein expression was also detected in white matter and cingulate gyrus nerve glial cells, which was similar to the results of (Della Valle et al., 2010) and (Avivi et al., 2010). It was considered that the expression of $\mathrm{Ngb}$ in nerve glial cells may be related to adaptation to the hypoxic environment. This present results found that the expression characteristics of HIF- $1 \alpha$ in both yak and cattle telencephalon, which were concentrated in the neuron cytoplasm, and were coincident with Ngb. The nerve glial cells in white matter and cingulate gyrus also were positive for HIF- $1 \alpha$, suggesting that Ngb and HIF- $1 \alpha$ may participate in plateau hypoxia endogenous protective mechanisms of neurons in yak brain tissue under the environment.

\section{Conclusion}

$\mathrm{Ngb}$ and HIF-1 $\alpha$ mRNA and protein are expressed in different regions of yak and cattle telencephalon, and located in the neuron cytoplasm and nerve glial cells, illustrating that the expression characteristics of Ngb and HIF- $1 \alpha$ were consistent in different regions of yak and cattle telencephalon, and they may have an important endogenous synergistic neuroprotection of yak and 
cattle telencephalon. The expression of Ngb and HIF-1 $\alpha$ in the parietal lobe showed higher as compared to other brain tissues, and reported to be tolerance to hypoxia in telencephalon of yak and cattle. As Compared with yak and cattle, it is found that the expression of Ngb protein in yak is higher than cattle, while the HIF- $1 \alpha$ protein expression in cattle is higher than yak, indicating that the yak and cattle telencephalon in different environment have different requirements for Ngb and HIF- $1 \alpha$.

\section{Acknowledgements}

The researchers extend heartfelt thanks and appreciation to the Gannan Tibetan Autonomous Prefecture and Zhengzhou prefecture for human and technical support during the collection of samples. This work could not have been possible without assistance rendered. The researchers extend heartfelt thanks and appreciation to the National Natural Science Foundation of China (Grant No. 31760305) for the financial and technical support. The funders had no role in study design, data collection, and analysis, decision to publish, or preparation of the manuscript.

\section{References}

ABHANG, P.A., GAWALI, B.W. and MEHROTRA, S.C., 2016. Introduction to EEG- and Speech-Based Emotion Recognition. USA: Elsevier Science. Introduction to emotion, electroencephalography, and speech processing, chap. 1, pp. 1-17.

AVIVI, A., GERLACH, F., JOEL, A., REUSS, S., BURMESTER, T., NEVO, E. and HANKELN, T. Neroglobin, cytoglobin, and myoglobin contribute to hypoxia adaptation of the subterranean mole rat Spalax. Proceedings of the National Academy of Sciences of the United States of America, 2010, vol. 107, no. 50, pp. 21570-21575. http://dx.doi.org/10.1073/pnas.1015379107.

AWENIUS, C., HANKELN, T. and BURMESTER, T., 2001. Neuroglobins from the zebrafish Danio rerio and the pufferfish Tetraodon nigroviridis. Biochemical and Biophysical Research Communications, vol. 287, no. 2, pp. 418-421. http://dx.doi. org/10.1006/bbrc.2001.5614. PMid:11554744.

BAI, Z.C., CUI, Y., YU, S.J., and XU, L., 2019 Expression and distribution of HIF- $1 \alpha$ and Beclin1 in adult yak brain tissue. Journal of Agricultural Biotechnology, vol. 27, pp. 1878-1884.

BANI HASHEMI, S., BRAUN, J., BERNHARDT, W.M., RASCHER, W., DÖTSCH, J. and TROLLMANN, R., 2008. HIF-1 alpha subunit and vasoactive HIF-1-dependent genes are involved in carbon monoxide-induced cerebral hypoxic stress response. European Journal of Applied Physiology, vol. 104, no. 1, pp. 95-102. http:// dx.doi.org/10.1007/s00421-008-0776-9. PMid:18560881.

BEAR, M.F., CONNORS, B.W. and PARADISO, M.A., 2007. Neuroscience: exploring the brain. 3rd ed. Filadélfia: Lippincott Williams \& Wilkins. Neuroscience: exploring the brain.

BURMESTER, T., WEICH, B., REINHARDT, S. and HANKELN, T., 2000. A vertebrate globin expressed in the brain. Nature, vol. 407, no. 6803, pp. 520-523. http://dx.doi.org/10.1038/35035093. PMid:11029004.

CASPERS, S. and ZILLES, K., 2018. Microarchitecture and connectivity of the parietal lobe. Handbook of Clinical Neurology, vol. 151, pp. 53-72. http://dx.doi.org/10.1016/B978-0-444-63622-5.000036. PMid:29519479.
CHENG, D.T., KATZENELSON, A.M., FAULKNER, M.L., DISTERHOFT, J.F., POWER, J.M. and DESMOND, J.E., 2020. Contingency awareness, aging, and the parietal lobe. Neurobiology of Aging, vol. 91, pp. 125-135. http://dx.doi.org/10.1016/j.neurobiolaging.2020.02.024. PMid:32241582.

CHERTOK, V.M. and KOTSYUBA, E.P., 2017. Localization and quantitative assessment of oxygen-sensitive hypoxia-inducible factor $1 \alpha$ in the brain of the mitten crab Eriocheir japonica in normal conditions and acute anoxia (an immunohistochemical study). Neuroscience and Behavioral Physiology, vol. 41, no. 1, pp. 12-16. http://dx.doi.org/10.1007/s11055-016-0360-4.

CHERTOK, V.M., NEVZOROVA, V.A. and ZAKHARCHUK, N.V., 2018. Comparative study of hif- $1 \alpha$ - and hif- $2 \alpha$-immunopositive neurons and capillaries in the rat cortex under conditions of tissue hypoxia. Bulletin of Experimental Biology and Medicine, vol. 165, no. 4, pp. 516-520. http://dx.doi.org/10.1007/s10517018-4207-6. PMid:30121923.

DELLA-VALLE, B., HEMPEL, C., KURTZHALS, A.L. and PENKOWA, M., 2010. In vivo expression of neuroglobin in reactive astrocytes during neuropathology in murine models of traumatic brain injury, cerebral malaria, and autoimmune encephalitis. Glia, vol. 58, no. 10, pp. 1220-1227. http://dx.doi.org/10.1002/glia.21002. PMid:20544857.

ERLER, J.T., CAWTHORNE, C.J., WILLIAMS, K.J., KORITZINSKY, M., WOUTERS, B.G., WILSON, C., MILLER, C., DEMONACOS, C., STRATFORD, I.J. and DIVE, C., 2004. Hypoxia-mediated down-regulation of Bid and Bax in tumors occurs via hypoxiainducible factor 1-dependent and -independent mechanisms and contributes to drug resistance. Molecular and Cellular Biology, vol. 24, no. 7, pp. 2875-2889. http://dx.doi.org/10.1128/ MCB.24.7.2875-2889.2004. PMid:15024076.

FABRIZIUS, A., ANDRE, D., LAUFS, T., BICKER, A., REUSS, S., PORTO, E., BURMESTER, T. and HANKELN, T., 2016. A critical re-evaluation of neuroglobin expression reveals conserved patterns among mammals. Neuroscience, vol. 337, pp. 339-354. http://dx.doi. org/10.1016/j.neuroscience.2016.07.042. PMid:27542528.

FORDEL, E., THIJS, L., MARTINET, W., LENJOU, M., LAUFS, T., VAN BOCKSTAELE, D., MOENS, L. and DEWILDE, S., 2007. Neuroglobin and cytoglobin overexpression protect human sh-sy5y neuroblastoma cells against oxidative stress-induced cell death. Neuroscience Letters, vol. 410, no. 2, pp. 146-151. http://dx.doi. org/10.1016/j.neulet.2006.09.027. PMid:17095159.

GUIDOLIN, D. TORTORELLA, C. MARCOLI, M., MAURA, G. and AGNATI, L.F., 2016. Neuroglobin, a factor playing for nerve cell survival. International Journal of Molecular Sciences, vol. 17, no. 11, pp. 1817. http://dx.doi.org/10.3390/ijms17111817.

HAINES, B., DEMARIA, M., MAO, X., XIE, L., CAMPISI, J., JIN, K. and GREENBERG, D.A., 2012. Hypoxia-inducible factor-1 and neuroglobin expression. Neuroscience Letters, vol. 514, no. 2, pp. 137-140. http://dx.doi.org/10.1016/j.neulet.2012.01.080. PMid:22342914.

HAN, S., BAI, Z.Z. and CAO, Y., 2017. Altitude hypoxia increases the expression of cerebral hemoglobin in the cerebral cortex of rats. Zhongguo Shengwuzhipinxue Zazhi, vol. 38, pp. 73-80.

HUNDAHL, C., STOLTENBERG, M., FAGO, A., WEBER, R.E., DEWILDE, S., FORDEL, E. and DANSCHER, G., 2005. Effects of short-term hypoxia on neuroglobin levels and localization in mouse brain tissues. Neuropathology and Applied Neurobiology, vol. 31, no. 6, pp.610-617. http://dx.doi.org/10.1111/j.1365-2990.2005.00657.x. PMid:16281909.

JU, C., COLGAN, S.P. and ELTZSCHIG, H.K., 2016. Hypoxia-inducible factors as molecular targets for liver diseases. Journal of Molecular Medicine (Berlin, Germany), vol. 94, no. 6, pp. 613-627. http:// dx.doi.org/10.1007/s00109-016-1408-1. PMid:27094811. 
LIANG, C., 2013. Distribution of brain hemoglobin in different tissues and cells of adult yak. Journal of Gansu Agricultural University, vol. 3, no. 4, pages 1-11.

LIU, N., YU, Z., XIANG, S., ZHAO, S., TJÄRNLUND-WOLF, A., XING, C., ZHANG, J. and WANG, X., 2012. Transcriptional regulation mechanisms of hypoxia-induced neuroglobin gene expression. The Biochemical Journal, vol. 443, no. 1, pp. 153-164. http:// dx.doi.org/10.1042/BJ20111856. PMid:22239089.

LÓPEZ-HERNÁNDEZ, B., POSADAS, I., PODLESNIY, P., ABAD, M.A., TRULLAS, R. and CEÑA, V., 2012. HIF-1 $\alpha$ is neuroprotective during the early phases of mild hypoxia in rat cortical neurons. Experimental Neurology, vol. 233, no. 1, pp. 543-554. http:// dx.doi.org/10.1016/j.expneurol.2011.11.040. PMid:22173319.

MEHLER, D.M.A. and RESCHECHTKO, S., 2018. Movement variability is processed bilaterally by inferior parietal lobule. The Journal of Neuroscience : The Official Journal of the Society for Neuroscience, vol. 10, no. 10, pp. 2413-2415. http://dx.doi.org/10.1523/ JNEUROSCI.3224-17.2018. PMid:30995608.

MOENS, L. and DEWILDE, S., 2000. Globins in the brain. Nature, vol. 407, no. 6803, pp. 461-462. http://dx.doi.org/10.1038/35035181. PMid:11028983.

MOHINDRA, V., TRIPATHI, R.K., SINGH, R.K. and LAL, K.K., 2013. Molecular characterization and expression analysis of three hypoxia-inducible factor-alpha subunits, hif- $1 \alpha,-2 \alpha$ and $-3 \alpha$ in hypoxia-tolerant Indian catfish, Clarias batrachus [Linnaeus, 1758]. Molecular Biology Reports, vol. 10, no. 10, pp. 5805-5815. http://dx.doi.org/10.1007/s11033-013-2685-1. PMid:24065526.

MONTIEL, J.F. and ABOITIZ, F., 2015. Pallial patterning and the origin of the iso-cortex. Frontiers in Neuroscience, vol. 9, pp. 377. http://dx.doi.org/10.3389/fnins.2015.00377. PMid:26512233.

REUSS, S., SAALER-REINHARDT, S., WEICH, B., WYSTUB, S., REUSS, M.H., BURMESTER, T. and HANKELN, T., 2002. Expression analysis of neuroglobin mRNA in rodent tissues. Neuroscience, vol. 115, no. 3, pp. 645-656. http://dx.doi.org/10.1016/S03064522(02)00536-5. PMid:12435404.

SEMENZA, G.L. and WANG, G.L., 1992. A nuclear factor induced by hypoxia via de novo protein synthesis binds to the human erythropoietin gene enhancer at a site required for transcriptional activation. Molecular and Cellular Biology, vol. 12, no. 12, pp. 5447-5454. PMID: 1448077.

SONG, L.L., CUI, Y., XIAO, L.F., YU, S. and HE, J., 2020. DHT and E2 synthesis-related proteins and receptors expression in male yak skin during different hair follicle stages. General and Comparative Endocrinology, vol. 286, pp. 113245. http://dx.doi. org/10.1016/j.ygcen.2019.113245. PMid:31415730.

SONG, L.L., CUI, Y., YU, S.J., LIU, P.G., LIU, J., YANG, X., HE, J.F. and ZHANG, Q., 2018. Expression characteristics of BMP2, BMPR-IA, and Noggin in different stages of the hair follicle in yak skin. General and Comparative Endocrinology, vol. 260, pp. 18-24. http://dx.doi.org/10.1016/j.ygcen.2017.11.016. PMid:29174869.
THE NEUROSCIENTIST, 2017. Perspectives on neuroscience and behavior. The Neuroscientist: a Review Journal Bringing Neurobiology, Neurology and Psychiatry, vol. 23, no. 5, pp. 439-440. http://dx.doi.org/10.1177/1073858417729988. PMid:30231838.

TONG-FANG L., 2014. Comparative study on the expression of encephaloglobin in different tissues of adult yak and cattle. Journal of Gansu Agricultural University, vol. 5, no. 6., pp. 1-8. In chinese.

VAN ACKER, Z.P, LUYCKX, E. and DEWILDE, S., 2019. Neuroglobin expression in the brain: a story of tissue homeostasis preservation. Molecular Neurobiology, vol. 56, no. 3, pp. 2101-2122. http://dx.doi.org/10.1007/s12035-018-1212-8. PMid:29992530.

VANGEISON, G., CARR, D., FEDEROFF, H.J. and REMPE, D.A., 2008. The good, the bad, and the cell type-specific roles of hypoxiainducible factor- $1 \alpha$ in neurons and astrocytes. The Journal of Neuroscience : The Official Journal of the Society for Neuroscience, vol. 28, no. 8, pp. 1988-1993. http://dx.doi.org/10.1523/ JNEUROSCI.5323-07.2008. PMid:18287515.

WOO, S.K., KWON, M.S., GENG, Z., CHEN, Z., IVANOV, A., BHATTA, S., GERZANICH, V. and SIMARD, J.M., 2001. Sequential activation of hypoxia-inducible factor 1 and specificity protein 1 is required for hypoxia-induced transcriptional stimulation of Abcc8. Journal of Cerebral Blood Flow and Metabolism: Official Journal of the International Society of Cerebral Blood Flow and Metabolism, vol.32, no. 3, pp. 525-536. http://dx.doi.org/10.1038/ jcbfm.2011.159. PMid:22086197.

WU, Q., WANG, Q., CHENG, X., ZHANG, X. and XIANG, J., 2008. The expression of HIF- $1 \alpha$ in different parts of the brain tissue of aged rats. Journal Medical University, vol. 10, pp. 1897-1899.

WYSTUB, S., LAUFS, T., SCHMIDT, M., BURMESTER, T., MAAS, U., SAALER-REINHARDT, S., HANKELN, T. and REUSS, S., 2003. Localization of neuroglobin protein in the mouse brain. Neuroscience Letters, vol. 346, no. 1-2, pp. 114-116. http:// dx.doi.org/10.1016/S0304-3940(03)00563-9. PMid:12850561.

YANG, C., LI, L., KOU, Z.T., ZHANG, H.H., WANG, L.M., ZHAO, Y., and ZHU, N., 2020. Telencephalon Cytoarchitecture of tsinling dwarf skinks (Scincella tsinlingensis). Micron, vol. 130, pp. 102799. http://dx.doi.org/10.1016/j.micron.2019.102799.

YAWNO, T., CASTILLOMELENDEZ, M., JENKIN, G., WALLACE, E.M., WALKER, D.W. and MILLER, S.L., 2012. Mechanisms of melatonininduced protection in the brain of late gestation fetal sheep in response to hypoxia. Developmental Neuroscience, vol. 34, no. 6, pp. 543-551. http://dx.doi.org/10.1159/000346323. PMid:23428588.

ZHANG, C., WANG, C., DENG, M., LI, L., WANG, H., FAN, M., XU, W., MENG, F., QIAN, L. and HE, F., 2002. Full-length cdna cloning of human neuroglobin and tissue expression of rat neuroglobin. Biochemical and Biophysical Research Communications, vol. 290, no. 5, pp. 1411-1419. http://dx.doi.org/10.1006/bbrc.2002.6360. PMid:11820779. 